\title{
Clinical Efficacy of Pathyadi Kwath Arka \& Katphala Churna Nasya in the Management of Ardhavabhedaka with special reference to Migraine - A pilot Study
}

\author{
Research Article
}

Shital Bolkuntwar ${ }^{*}$

1. Assistant Professor and PhD Scholar, Department of Shalakyatantra,

D Y Patil School of Ayurveda, Nerul, Navi Mumbai-410210. India.

\begin{abstract}
Ardhavabhedaka can be correlated with migraine having similar symptom as half-sided headache. It is mentioned as tridoshapradhana by Sushruta and vatakaphapradhana by Vagbhata. Pathyadi Kwath is a proven formulation for urdhwajatrugata disorders including Ardhavabheaka. In addition, importance of Nasya karma in shirogata vyadhi cann't be ignored so here pradhamana nasya with kataphala churna mentioned in Yogaratnakara is selected to evaluate its efficacy. Aim \& Objective: The present study aimed to evaluate the clinical efficacy of Pathyadi Kwath Arka \& Katphala Churna Nasya in the management of Ardhavabhedaka with special reference to Migraine. Material and method: The fruit of haritaki, bibhitaki, Amalaki, stem bark of nimba, whole plant of bhunimba, rhizome of haridra and stem of guduchi were used for the preparation of Pathyadi Kwath and its extract (arka) was prepared using the same ingredients by the process of distillation. Course powder of Kataphala was prepared in grinder, then filtered from mesh size 500 micron (BS 30, ASTM 35) and smooth powder of Kataphala obtained. Botanists carried out authentication of drugs. The study conducted on 10 samples for the duration of 12 weeks. Pathyadi kwath given in the dose of $10 \mathrm{drops} / 10 \mathrm{ml}$ of water and kataphala churna pradhaana nasya; morning and evening daily. Result: Statistically significant $\mathrm{p}$ value was noted i.e. $(\mathrm{P}<0.05)$, the null hypothesis is accepted, hence it is clear that all the parameters show a significant difference in the observations (before treatment and after treatment). Conclusion: Pathyadi Kwath Arka \& Katphala Churna Nasya is effective in the management of Ardhavabhedak.
\end{abstract}

Key Words: Ardhavabhedaka, Headache, Migraine, Pathyadi Kwath Arka, Katphala churna, Pradhamana nasya.

\section{Introduction}

"Shira" described as one of the three marma. (1) It has given prime importance to being the site of prana (vital force) \& sense organs. (2)Acharya Charaka has mentioned ten sites of prana among which there are two-shankha pradesha and one shira. (3)Conduction of impulses from different parts of the body carried out by Majja tantu (nerves) via prana vayu (vital energy). Tarpaka kapha (Majja dhathu) provides nutrition to the important structures in the brain \& heat regulation achieved with bhrajaka pitta. Acharya vagbhata described the body as Urdhwamoola adhoshakha i.e. shira considered as moola (root) and body as branches. (4) In order to raise tree nourishment and care of roots is very necessary; they are responsible for the stability of the tree. Vital points in shira (shirogata marma), nerves (Majjatantu) are responsible for bodily

* Corresponding Author:

Shital Bolkuntwar

Assistant Professor and PhD Scholar,

Department of Shalakyatantra,

D Y Patil School of Ayurveda, Nerul, Navi

Mumbai-410210. India.

Email Id: Shituu.bolkuntwar07@gmail.com movement, metabolism, stability, and protection. Any trauma or disease of the head can affect the overall health of the body.

Sushruta explains 11 types of shiroroga. Viz vataj, Pittaj, Kaphaj, Sannipataj, Raktaj, Krimij, Kshaya, Suryavarta, Anantavata, Ardhavabhedak, Shankhak.(5) The disease in which headache is a prime symptom is known as shiroroga. The name is not given according to the site of the disease, so sushruta does not mention nine-kapalagata roga in shiroroga for not having shira shoola but vagbhata explained these 9 diseases in shiroroga as kapala rogas. Vaghbata has given 10 shirogata and nine kapalagata roga, he has not mentioned ananatavata and kshayaja shiroroga rather explain shirokampa.(6) Among these Ardhavabhedaka is commonly seen to affect the young population because of the increased etiological factors like consumption of dry bakery items in excess, keto diet in teenagers to reduce weight, long hours working in AC, suppression of natural urges, excess workout in gym, etc. Ardhavbhedaka can be correlated with migraine characterized by pain in half side of the head. (7) According to Charaka Vata either alone or in combination with Kapha, seizes the one half of the head and causes Ativedana (acute neuralgic pain) in the sides of the Manya (neck), Bhroo (eyebrow), Shankha (temple), Karna (ear), Akshi (eyes) or Lalatardhe (the 
forehead of one side). This pain is very agonizing like that of a churning rod (red-hot needle). If the condition becomes aggravated, it may even deteriorate the Nayana (eye) and Karna (ear). (8)

Migraine documented as a chronic illness, the second most common cause of headache. Nearly 15\% or approximately one billion people affected by migraine. It is more common in women $19 \%$ than men $11 \%$ (9) during early stages, migraine becomes more common among females (10) and persists for the rest of the lifespan, and more common among elderly females than males. (11) The pain of migraine often occurs on one side and occasionally spreads to affect the entire head thus the word migraine have close resemblance with Greek word Hemicrania, meaning "half of the head". The term "migraine" refers to a disorder of vascular spasms of the cranial blood vessels. Usually, an episodic headache is associated with certain features such as sensitivity to light, sound, movement; nausea, vomiting, and headache. (12) The pattern of disease has grossly changed with the arrival of modern drugs, but the drugs only reduce the symptoms temporarily and the underlying pathology goes on progressively worsen the condition. Though ample research is being carried out to alleviate the disease and new avenues are being explored for treating the early stage of the disease, there is no satisfactory treatment for Migraine.

So here sincere effort in the form of a pilot study was taken to evaluate the clinical efficacy of pathyadik wath in the form of Arka (13) and kataphala churna(14) were selected for the present study used in the treatment of Ardhavabedaka.

\section{Rationale / Need of the study:}

Treatment of Migraine available at present includes the use of analgesics and vasodilators. They have an insignificant role in achieving success but have adverse effects. The present scenario encourages exploring newer, efficacious drugs/procedures to tackle such disease entities. Pathyadi Kwath recommended in Sharangdhara Samhita for headache (migraine, cluster headache), earache, dental pain, pain in the eye, night blindness. The positive effect of pathyai Kwath in Ardhavabhedaka has proven in various studies. (15) The only difficulty in consumption of the drug is palatability and Patient compliance is one of the important aspects of research study, the palatable form of the drug will definitely reduce the dropout of patients while conducting research. So for the present study, form of the drugs is changed i.e. Arka (extract) is prepared to test whether it is equally effective in Ardhavabhedaka as Pathyadi kwath. Comparative Phytochemical Analysis of Pathyadi Kwath \& Pathyadi Kwath Arka with their Standardization By HPTLC has been done on comparing the $\mathrm{Rf}$ values it was found that both the kwath and Arka consisted of andrographaloide. On comparing the AUC it can be said that both the formulations kwath and arka consisted of equal concentrations of andrographaloide.

In addition, the best route to eliminate shirogata-accumulated doshas is via nasal route i. e. Nasya. Nose is the main entry point to reach up to shiropradesha. (16) The importance of Nasya karma in the treatment of headache disorders cannot be ignored. Thus, oral administration of Pathyadi kwath Arka along with Kataphala churna pradhamana Nasya was the treatment of choice.

\section{Aims and objectives}

To evaluate the clinical efficacy of Pathyadi Kwath Arka \& Katphala Churna Nasya in the management of Ardhavabhedaka with special reference to Migraine.

\section{Null Hypothesis Ho}

Pathyadi Kwath Arka \&Katphala Churna Nasya is effective in the management of Ardhavabhedaka.

\section{Alternative Hypothesis H1}

Pathyadi Kwath Arka \& Katphala Churna Nasya is not effective in the management of Ardhavabhedaka.

\section{Materials and Methods}

Plant Material: Raw drugs purchased from Malhar Ayurved drugs wholesale distributor, Nerul. Authentification of raw drugs carried out by Botanist (ref no. 08192131)

Pathyadi Kwath Ark: Colorless extract prepared by using same drugs as in pathyadi kwath by the process of distillation.

Table: - 1 Ingredients of Pathyadi Kwath

\begin{tabular}{|c|c|c|c|c|}
\hline Sr. No. & Name of the drug & Botanical name of the drug & Part used & $\begin{array}{c}\text { Proportion of the } \\
\text { drug }\end{array}$ \\
\hline 1 & Haritaki & Terminalia chebula (Retz) & Fruit & 1 part \\
\hline 2 & Bhibhitaki & Terminalia bellirica (Gaertn) Roxb & Fruit & 1 part \\
\hline 3 & Amalaki & Phyllanthus emblica (L) & Fruit & 1 part \\
\hline 4 & Nimb & Azadiracta indica (A. Juss) & Stem bark & 1 part \\
\hline 5 & Bhunimba & Andrographis paniculata (Burm) & Whole plant & 1 part \\
\hline 7 & Haridra & Curcuma longa( Linn) & Rhizome & 1 part \\
\hline
\end{tabular}

\section{Preparation of Pathyadi Kwath Arka - Duration 1 hour 5 minute min}

Pathydi Kwath Arka (extract) was prepared by using a standard method described in Arkaprakash (17) in Rasashastra and Bhaishajya kalpana department, D. Y. Patil School of Ayurveda, Nerul Navi Mumbai. Arkaprakash is the first Ayurvedic classical text in which various kinds of distillation procedure and 
heating methods has mentioned for preparing arka. Total 210 gm of drug (coarse) taken, each 30 gm soaked with twice quantity of water and kept overnight (12 hours), next day water is added equal to the quantity of drug and transferred to distillation apparatus. Aka obtained collected in transparent borosil jar (Fig 1).

Table: - 2 Total quantity of ingredients and yield obtained in the preparation of drug

\begin{tabular}{|c|c|c|c|c|c|c|c|c|}
$\begin{array}{c}\text { Quantity of } \\
\text { drugs }\end{array}$ & $\begin{array}{c}\text { Quantity of } \\
\text { water }\end{array}$ & $\begin{array}{c}\text { Total } \\
\text { weight }\end{array}$ & $\begin{array}{c}\text { Quantity of } \\
\text { final product }\end{array}$ & $\begin{array}{c}\text { Commencement } \\
\text { time }\end{array}$ & $\begin{array}{c}\text { Boiling } \\
\text { time }\end{array}$ & $\begin{array}{c}\text { First drop } \\
\text { time }\end{array}$ & $\begin{array}{c}\text { Finished } \\
\text { time }\end{array}$ & $\begin{array}{c}\text { Time } \\
\text { required }\end{array}$ \\
\hline $210 \mathrm{gm}$ & $630 \mathrm{ml}$ & $890 \mathrm{gm}$ & $400 \mathrm{ml}$ & $2.40 \mathrm{pm}$ & $\begin{array}{c}2.45 \\
\mathrm{Pm}\end{array}$ & $\begin{array}{c}2.55 \\
\mathrm{Pm}\end{array}$ & $3.45 \mathrm{pm}$ & $\begin{array}{c}1 \mathrm{hr} 5 \\
\mathrm{~min}\end{array}$ \\
\hline
\end{tabular}

Katphal Churna - Raw drug of Katphala purchased from Malhar Ayurved drugs wholesale distributor, Nerul. Course powder of Kataphala was prepared in grinder, then filtered from mesh size 500 micron (BS 30, ASTM 35) and smooth powder of Kataphala obtained Authentication of raw drug was carried out by Botanist (ref no. 0812219)(Fig 2).

Figure 1

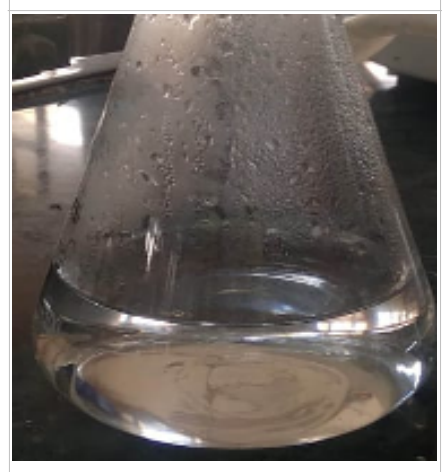

|Table: - 3 Dose and Duration Pathyadi Kwath Arka.

10 drops with $10 \mathrm{ml}$

Dose of warm water Morning and evening
Figure 2

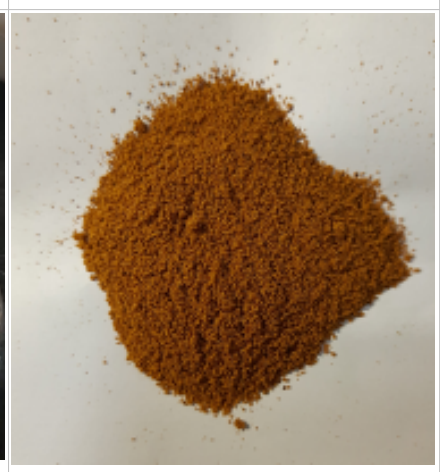

Kataphala Churna Pradhamana Nasya Muchunti pramana (amount of drug obtained between index finger \& thumb, after sharply squeezing, gripping, pinching)

\begin{tabular}{l|l|l|}
$\begin{array}{l}\text { Durat } \\
\text { ion }\end{array}$ & $12 \mathrm{wk}$ & $12 \mathrm{wk}$
\end{tabular}

\section{Inclusion and Exclusion Criteria}

Inclusion Criteria

- Age: 18 to 45 years.

- Patients presenting with signs and symptoms of Migraine described as per Ayurvedic and modern science.

\section{Exclusion Criteria}

- Pregnant and lactating women.

- Ophthalmologic migraine and Complicated migraine

- Patients using drugs for any other systemic illness.

- Patients suffering from major disease e.g. tuberculosis, cancer, diabetes mellitus, heart disease, hypertension etc.

- Secondary Headache caused by sinusitis, meningitis, brain tumor, encephalitis, cervical spondylitis, refractive error and increased intra ocular pressure
The diagnosis based on the criteria of Migraine provided by International Headache Society. (18)

- At least 5 attack in the history fulfilling criteria B-D

- Headache attacks lasting 4-72hours.(untreated or unsuccessfully treated)

- Headache has at least 2 of the following characters

- Unilateral location

- Pulsating quality.

- Moderate or severe pain intensity.

- Aggravation by or causing avoidance of routine physical activity(e.g. walking or climbing stairs)

- During headache at least one of the following

- Nausea and/or vomiting

- Photophobia and phonophobia

- Not better accounted for by another ICHD-3 diagnosis.

\section{Criteria for Assessment}

Pilot study conducted on 10 patients selected randomly irrespective of, sex, religion, education etc. Follow up has been carried out on 0, 2 wk., 4wk, 6wk, $8 \mathrm{wk}$, and $10 \mathrm{wk} 12 \mathrm{wkThe}$ assessment will be done before, during and after the treatment and results will be analyzed statistically as per the assessment chart.

\section{Pain Assessment Scale $(19,20)$}

Donna Wong and Connie Baker developed this pain scale having six faces. It shows the series of faces range from happy face at ' 0 ' or no hurt to a crying face at ' 10 ' or worst pain. Originally, this scale was developed for children and illiterate patients because they may not able to tell exact degree of pain so these cartoon faces can help to assess their severity. In the current study, scale was used to assess severity of headache (pain) in migraine patients in which patient have to choose face denoting his/her present situation.

Grading of severity of pain is done from 0 to 5 in which grade 0 represent first happy face i.e. 0 in pain scale. Grade 1 represent second face i.e. (1-2) in pain scale. Third face is represented by grade 2 i.e. (3-5) in pain scale. Grade 3 represented by forth face i.e. 6 in pain scale. Grade 4 represented by fifth face i.e. (7-9) in pain scale, and sixth face is represented by grade 5 i.e. 10 in pain scale. 
Numeric pain intensity scale

\section{Figure - 3}

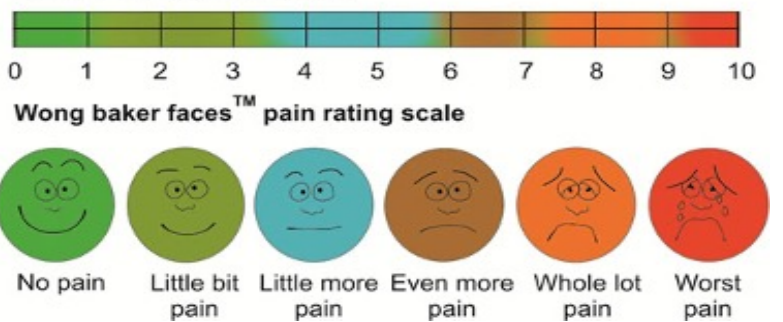

Table: - 4 Grading for assessment of the symptoms

The severity of Pain

$0 \quad$ No pain $(0)$

1 Intermittent mild pain i.e. bearable (1-2)

2 Continuous mild pain not disturbing routine work (3-5)

3 Continuous moderate pain(bearable) not disturbing

3 the routine work (6)

4 Continuous severe pain disturbing the routine

work(7-9)

5 Severe (non-bearable ) pain (10)

Nausea

$0 \quad$ Nil

1 Occasionally

2 Moderate, can ignore at times

3 Severe, disturbing routine work

4 Severe enough, a small amount of fluid regurgitating from mouth

Duration of the pain

0 No pain

minute $-3 \mathrm{~h}$

4-12 h

$13-24 \mathrm{~h}$

Over $24 \mathrm{~h}$ or continuous

Vomiting

$0 \quad$ Nil

1 Only if the pain does not subside

2 Vomiting 1-2 times

3 Vomiting 2-3 times

4 Forced to take medicine to stop vomiting

Frequency of attack

\section{No attack \\ 1 Once in 21-30 days \\ 2 Once in 11-20 days \\ 3 Once in 1-10 days \\ 4 Continuous/daily}

\section{Vertigo}

\section{$0 \quad$ Nil}

1 Feeling of giddiness

2 Patients feels as if everything is revolving

3 Revolving sign and blackout

4 Unconscious

\section{Photophobia}

\section{$0 \quad$ Nil}

1 Intolerance of bright sunlight

2 Mild pain occurring upon exposure of light

3 Moderate pain occurring upon exposure of light

4 Severe pain occurring upon exposure of light

\section{Associated symptoms}

\begin{tabular}{|l|l|}
\hline 0 & No symptoms \\
\hline 1 & Mild can do his/her work \\
\hline 3 & Moderate forced to stop work \\
\hline 4 & Severe forced to take rest \\
\hline & Excruciating forced to take medicine \\
\hline
\end{tabular}

Associated Symptoms are - Tinnitus, Phonophobia, Aura, Numbness, Heaviness in head, Tenderness, Diarrhea, and Confusion

\section{Observations}

Pilot study conducted on 10 patients to evaluate clinical efficacy of Pathyadi Kwath Arka and Kataphala churna pradhamana nasya in management of Ardhavabhedaka. All the study parameters observed as per representation gradation done before and after treatment given.

\section{Fig: - 4 Graphical representation given as below}

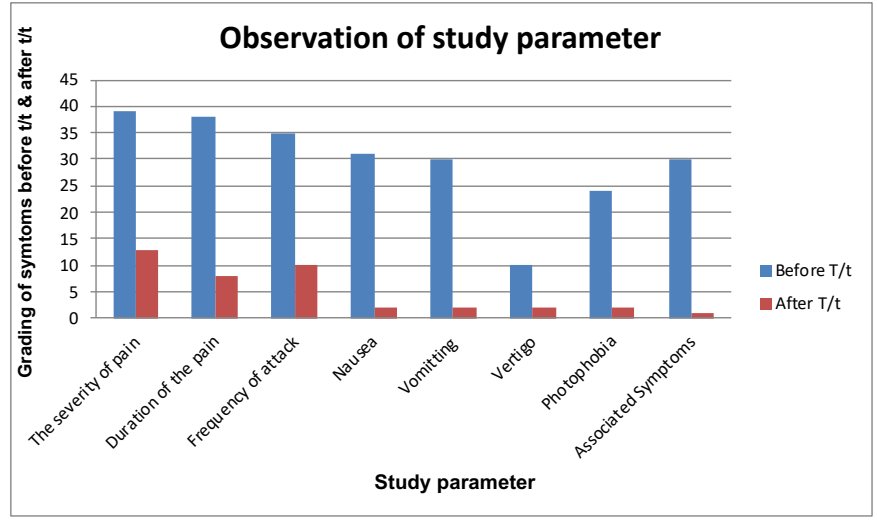

Table: 5 Tabular observation given as below

\begin{tabular}{|c|c|c|c|c|}
\hline Parameters & $\begin{array}{l}\text { Before } \\
\text { T/t }\end{array}$ & $\begin{array}{l}\text { After } \\
\text { T/t }\end{array}$ & $\begin{array}{l}\text { Percent } \\
\text { Relief }\end{array}$ & Result \\
\hline $\begin{array}{l}\text { The severity of } \\
\text { pain }\end{array}$ & 39 & 13 & 67 & $\begin{array}{l}\text { Good } \\
\text { Relief }\end{array}$ \\
\hline $\begin{array}{l}\text { Duration of the } \\
\text { pain }\end{array}$ & 38 & 8 & 79 & $\begin{array}{l}\text { Good } \\
\text { Relief }\end{array}$ \\
\hline $\begin{array}{l}\text { Frequency of } \\
\text { attack }\end{array}$ & 35 & 10 & 71 & $\begin{array}{l}\text { Good } \\
\text { Relief }\end{array}$ \\
\hline Nausea & 31 & 2 & 94 & $\begin{array}{l}\text { Excellent } \\
\text { Relief }\end{array}$ \\
\hline Vomiting & 30 & 2 & 93 & $\begin{array}{l}\text { Excellent } \\
\text { Relief }\end{array}$ \\
\hline Vertigo & 10 & 2 & 80 & $\begin{array}{l}\text { Good } \\
\text { Relief }\end{array}$ \\
\hline Photophobia & 24 & 2 & 92 & $\begin{array}{l}\text { Excellent } \\
\text { Relief }\end{array}$ \\
\hline $\begin{array}{l}\text { Associated } \\
\text { Symptoms }\end{array}$ & 30 & 1 & 97 & $\begin{array}{l}\text { Excellent } \\
\text { Relief }\end{array}$ \\
\hline
\end{tabular}

The above table shows the total relief in the parameter. The severity of pain, Duration of the pain, Frequency of attack is $67 \%, 79 \%, \& 71 \%$ respectively indicating good relief. Commonly seen symptoms in migraine Nausea and Vomiting shows excellent relief i.e. $94 \%$ and $93 \%$. Vertigo which seems to be difficult to cure shows $80 \%$ relief. Photophobia (Intolerance to bright light) got excellent relief i.e. 92\%. Associated symptoms Tinnitus, Phonophobia, Aura, Numbness, Heaviness in head, Tenderness, Diarrhea, and Confusion that are seen in the patients of migraine in little or more concentration gave excellent relief $i$. e. $97 \%$. 
Effect of therapy on system score by Wilcoxon Signed Rank test

Table: - 6 Data generated was single grouped and ordinal and analyzed using Wilcoxon Sign Ranked Test.

\begin{tabular}{|c|c|c|c|c|c|c|c|c|c|}
\hline Parameter & Observation & MIN & MAX & MED & SD & SE & $\mathbf{W}$ & $P$ value & Result \\
\hline \multirow{2}{*}{$\begin{array}{l}\text { Severity of } \\
\text { Headache }\end{array}$} & BT & 2 & 5 & 4 & 0.9944 & 0.9487 & \multirow{2}{*}{55} & \multirow{2}{*}{0.001} & \multirow{2}{*}{ Significant } \\
\hline & AT & 0 & 3 & 1 & 0.3145 & 0.3000 & & & \\
\hline \multirow{2}{*}{$\begin{array}{l}\text { Duration of } \\
\text { Headache }\end{array}$} & BT & 3 & 4 & 4 & 0.4216 & 0.6325 & \multirow{2}{*}{55} & \multirow{2}{*}{0.001} & \multirow{2}{*}{ Significant } \\
\hline & AT & 0 & 2 & 1 & 0.1333 & 0.2000 & & & \\
\hline \multirow{2}{*}{$\begin{array}{l}\text { Frequency of } \\
\text { Headache }\end{array}$} & BT & 2 & 4 & 4 & 0.7071 & 0.8165 & \multirow{2}{*}{55} & \multirow{2}{*}{0.001} & \multirow{2}{*}{ Significant } \\
\hline & AT & 0 & 2 & 1 & 0.2236 & 0.2582 & & & \\
\hline \multirow{2}{*}{ Nausea } & BT & 2 & 4 & 3 & 0.7379 & 0.2330 & \multirow{2}{*}{55} & \multirow{2}{*}{0.001} & \multirow{2}{*}{ Significant } \\
\hline & AT & 0 & 1 & 0 & 0.4216 & 0.1333 & & & \\
\hline \multirow{2}{*}{ Vomiting } & BT & 1 & 4 & 3 & 0.9428 & 0.2981 & \multirow{2}{*}{55} & \multirow{2}{*}{0.001} & \multirow{2}{*}{ Significant } \\
\hline & AT & 0 & 1 & 0 & 0.4216 & 0.1333 & & & \\
\hline \multirow{2}{*}{ Vertigo } & BT & 0 & 2 & 1 & 0.6670 & 0.2108 & \multirow{2}{*}{36} & \multirow{2}{*}{0.0039} & \multirow{2}{*}{ Significant } \\
\hline & AT & 0 & 1 & 0 & 0.3162 & 0.1000 & & & \\
\hline \multirow{2}{*}{ Photophobia } & BT & 1 & 4 & 2 & 0.9661 & 0.3055 & \multirow{2}{*}{55} & \multirow{2}{*}{0.001} & \multirow{2}{*}{ Significant } \\
\hline & AT & 0 & 2 & 0 & 0.6325 & 0.2000 & & & \\
\hline \multirow{2}{*}{$\begin{array}{l}\text { Associated } \\
\text { Symptoms }\end{array}$} & BT & 2 & 4 & 3 & 0.8165 & 0.2582 & \multirow{2}{*}{55} & \multirow{2}{*}{0.001} & \multirow{2}{*}{ Significant } \\
\hline & AT & 0 & 1 & 0 & 0.3182 & 0.1000 & & & \\
\hline
\end{tabular}

From the above table $(\mathrm{P}<0.05)$, null hypothesis is accepted, hence it is clear that all the parameters show significant difference in the observations (before treatment and after treatment). We can conclude the drug is effective Pathyadi Kwath Arka \& Katphala Churna Nasya is effective in management of Ardhavabhedaka

\section{Discussion}

Pathydi Kwath Arka (extract) prepared by using standard method described in Arkaprakashhaving same Properties as Pathyadi Kwath, the only difference is its colorless nature.Arka was prepared by the process of distillation in distillation apparatus.

Table: - 7 Properties of Pathyadi Kwath Arka

\begin{tabular}{|c|c|c|c|c|c|c|}
\hline Sr. No. & Name & Rasa & Guna & Veerya & Vipaka & Prabhav \\
\hline $\mathbf{1}$ & Haritaki & 5 rasas except lavana & Laghu, Ruksha. & Ushna & Madhura & Tridoshahara \\
\hline $\mathbf{2}$ & Vibhitaki & Kashaya & Laghu, Ruksha & Ushna & Madhura & Kaphapittahar \\
\hline $\mathbf{3}$ & Amalaki & $\begin{array}{c}\text { 5rasas except Lavana, Amla } \\
\text { rasa pradhana }\end{array}$ & Laghu Ruksha Sheeta & Sheeta & Madhura & Tridoshahara \\
\hline $\mathbf{4}$ & Nimba & Tikta Kashaya & Laghu, Ruksha. & Sheeta & Katu & Kaphapittahar \\
\hline $\mathbf{5}$ & Bhunimba & Tikta & Laghu, Ruksha. & Sheeta & Katu & Kaphapittahar \\
\hline $\mathbf{6}$ & Haridra & Tikta Katu & Laghu, Ruksha, & Ushna & Katu & Kaphavatahara \\
\hline $\mathbf{7}$ & Guduchi & Tikta, kashaya. & Laghu,Snigdha. & Ushna & Madhur & Tridoshahara \\
\hline
\end{tabular}

Percentage was drawn by considering total as $100 \%$ i.e. fortotal of any rasa or guna present in the all seven drug. For e.g. number of tikta rasa in seven drugs was six so its percentage drawn as $86 \%$.

Table: - 8 Rasa, guna, veerya, veepaka, doshaghnata of this indigenous compound described as follows

\begin{tabular}{|c|c|c|c|}
\hline Sr. no. & Properties & Number & Percentage \\
\hline 1. Rasa & $\begin{array}{l}\text { Madhura } \\
\text { Amla } \\
\text { Katu } \\
\text { Tikta } \\
\text { Kashava }\end{array}$ & $\begin{array}{l}2 \\
2 \\
3 \\
6 \\
5\end{array}$ & $\begin{array}{l}29 \% \\
29 \% \\
43 \% \\
86 \% \\
71 \%\end{array}$ \\
\hline 2. Guna & $\begin{array}{l}\text { Snigdha } \\
\text { Laghu } \\
\text { Ruksha } \\
\text { Sheeta }\end{array}$ & $\begin{array}{l}1 \\
7 \\
6 \\
1\end{array}$ & $\begin{array}{l}14 \% \\
100 \% \\
86 \% \\
14 \%\end{array}$ \\
\hline 3.Veerya & $\begin{array}{l}\text { Sheeta } \\
\text { Ushna }\end{array}$ & $\begin{array}{l}3 \\
4\end{array}$ & $\begin{array}{l}43 \% \\
57 \%\end{array}$ \\
\hline 4.Vipaka & $\begin{array}{l}\text { Madhuar } \\
\text { Amla } \\
\text { Katu }\end{array}$ & $\begin{array}{l}4 \\
0 \\
3\end{array}$ & $\begin{array}{l}57 \% \\
0 \% \\
43 \%\end{array}$ \\
\hline $\begin{array}{l}\text { 5.Doshag } \\
\text { hnata }\end{array}$ & $\begin{array}{l}\text { Tridoshhara } \\
\text { Kaphapittahara } \\
\text { Kaphavatahara }\end{array}$ & $\begin{array}{l}3 \\
3 \\
1\end{array}$ & $\begin{array}{l}43 \% \\
43 \% \\
14 \%\end{array}$ \\
\hline
\end{tabular}

1. Rasa - In Combination, the drug contains all five except lavanarasa. It contains Tikta rasa in maximum percentage i.e. $86 \%$, kashayarasa $71 \%$, katu rasa 43\%, Madhur \& amla rasa each 29\%,

2. Guna- The different Gunas described in the Ayurvedic literature about indigenous drugs. Out of these Pathyadi kwath possesses $100 \%$ laghu guna while Ruksha guna is $86 \%$, and Snigdha \& sheet guna is $20 \%$ each.

3. Vipaka - This drug possesses Madhur Vipaka in maximum percentage i.e. 57\% \&katu vipaka $43 \%$.

4. Veerya-Percentage of the drug for ushna veerya is $57 \%$ and sheet veerya is $43 \%$

5. Doshaghnata - Tridoshhara and kaphapittahara in $43 \%$ each.

It is clear from the above table that Pathyadi Kwath Arka is tikta kashaya rasa pradhana, having madhur vipaka and ushna veerya with laghu \& ruksha guna predominance. As per Acharya Sushruta Ardhavabhedaka is said Tridoshapradhan and charak said it as Vatakaphapradhana doshadushti.However, 
practically most of the patients with migraine are seen having hyperacidity, history of consumption of street food, spicy food, night out, stressful lifestyle these are described as pittaprakopaka hetues in Ayurveda, which are responsible for nausea, vomiting, vertigo. So considering pitta predominance in Ardhavabhedaka tikta kashaya and madhur vipaka of Pathyadi kwath will be best pittashamaka dravya. Katu and tikta rasa of pathyadi kwath have deepana, pachana karmathat helps to improve metabolism by the property of Amapachana. usna veerya of pathyadi kawth act as strotoshodhaka and kledashoshaka; eliminate morbid doshas accumulated in the body.

Though the percentage of ushna veerya dravya are $57 \%$ it is not that high to cause pittaprakopa rather it balances associated kaphadosh in Ardhavabhedaka. In addition, laghu and ruksha guna act as kleda shoshaka, mala of kapha dosh. All we can say pathaydi kwath is the formulation that can break the samprapti of Ardhavabhedaka.

Phytochemical Analysis Between Pathyadi Kwath \& Pathyadi Kwath Arka and Its Standardization By HPTLC was carried out to evaluate the presence of active ingredient Andrographaloide in both the sample. On comparing the Rf values it was found that both the $k$ wath and arka consisted of andrographaloide. On comparing the AUC it can be said that both the formulations kwath and arka consisted of equal concentrations of andrographaloide.

\section{Table: - 9 Properties of Kataphala churna}

\begin{tabular}{|l|l|}
\hline Sr. No. & $\mathbf{1}$ \\
\hline Name & Kataphala \\
\hline Rasa & Kashaya, Tikta, Katu \\
\hline Guna & Laghu, Tikshna \\
\hline Veerya & Ushna \\
\hline Vipak & Katu \\
\hline Prabhav & Kapha vatahara \\
\hline
\end{tabular}

Kataphal is described in vedanasthapaka gana(21) thus definitely helps to reduce the severity of pain in ardhavbhedaka. Pradhamana nasya is the shodhana type of nasya in which drug inhaled in the form of powder (churna) in the dose of Muchuntipramana (A pinch i.e. to firmly squeeze or grip between your thumb and finger). For the present study,nasya was given daily Morning and evening. The mode of action of the drug explained as below:

Acharya Vagbhata explains nose as the door for shira i.e. drug administered via nasal route helps to eliminate shirastha-vitiated dosha. The drug will reach shringataka marma,(22) spreads upon nasa, shrotra, akshi, jivha, murdha through their siras and helps to expel out accumulated doshas in urdhwajatru pradesh. Drug has given via nasya absorbed by mucosal lining of the nose and paranasal sinuses and reaches up to the olfactory area from where it spread within the higher center of the brain including pituitary, thalamus, hypothalamus, and limbic system through olfactory nerve terminals. From the olfactory nerve receptor, it can reach up to the intracranial structures. Thus, nasya with katphala churna work in Ardhavabhedaka with its vatahara and vedanasthapaka properties.

\section{Conclusion}

A current study shows pathyadi kwath and katphala churna nasya are effective in the management of Ardhavabhedaka. Pathyadi kwath is the proven formulation mentioned in sharangdharsamhita for Shirashula has the best result, used in the form of arka for the present study. Liquid preparation obtained by distillation of certain liquid or drugs drenched in water using Arkayantra or any convenient modern distillation apparatus called Arka Kalpana. The Concept of Arka as dosage form seen in different texts but the pharmaceutical aspect of arka kalpana is mention in detail mainly in Ravana's Arka Prakash. Shirashulahara yoga (Arka) (23) mentioned in Arkaprakash has the same ingredients as in pathyadi kwath. Arka Kalpana can be the better substitute because of having more potency in comparison to the other kalpanas. It is the most potent due to dosharahithatva and its specific gunas. It is having increased potency, reduced dose, more shelf life and also easy absorption, fast action, and patient compliance. Once arka is prepared, it can be stored for at least six months, convenient to carry, required in minimum dose, and palatable as well. Such a palatable form of the drug will definitely reduce dropout of patients while conducting a research study.

\section{Limitation of the study}

Though the shelf life of arka mentioned as six months, in the humid atmosphere in Mumbai it was difficult to store for more than four-months. More and more experiments on the preparation and preservation of arka should be done to prove its shelf life.

\section{Clinical Significance}

Consumption of drugs in the form of Arka will simplify research study by reducing difficulty related to the trial drug.

\section{Reference}

1. Priyavrat Sharma, Charaka Samhita of Acharya Charaka, Eighth edition 2007; Varanasi, Chaukambha Orientalia publishers, Chikitsathana 26/3, Page no. 420

2. Priyavrat Sharma, Charaka Samhita of Acharya Charaka, Eighth edition 2007; Varanasi, Chaukambha Orientalia publishers, Sutrasthana 17/11, Page no. 115

3. Priyavrat Sharma, Charaka Samhita of Acharya Charaka, Eighth edition 2007; Varanasi, Chaukambha Orientalia Publishers, Sutrasthana 29/3,4, Page no. 232

4. Ganesh Krushna Garde, Astanga Hridayam of Acharya Vagbhata, 2019 edition; Varanasi, Chaukhambha Surabharati Prakashana, Uttar-tantra 24/58, Page no. 428

5. Kaviraja Ambikadatta Shastri, Sushruta Samhita of Acharya sushruta, 2018 edition, Varanasi (with Ayurved Tattva Sandipika, hindi commentary) Chaukhamba Sanskrit sansthan, Uttara-tantra 25/3,4, page no 159 
6. Ganesh Krushna Garde, Astanga Hridayam of Acharya Vagbhata, 2019 edition; Varanasi, Chaukhambha Surabharati Prakashana, Uttar-tantra 23/20, Page no.423,424

7. Ganesh Krushna Garde, Astanga Hridayam of Acharya Vagbhata, 2019 edition; Varanasi, Chaukhambha Surabharati Prakashana, Uttar-tantra 23/7, Page no.423

8. Priyavrat Sharma, Charaka Samhita of Acharya Charaka, Eighth edition 2007; Varanasi, Chaukambha Orientalia publishers, Siddhisthana 9/75,76, Page no.653

9. Flaxman AD, Naghavi M, Lozano R, Michaud C, Ezzati $\mathrm{M}$ et al.; Years lived with disability (YLDs) for 1160 sequelae of 289 diseases and injuries 1990-2010: a systematic analysis for the Global Burden of Disease Study 2010. Lancet, 2012; 380 (9859): 2163-2196.

10. Hershey AD; Current approaches to the diagnosis and anagement of pediatric migraine. Lancet Neurology, 2010; 9(2): 190-204.

11. Nappi RE, Sances G, Detaddei S, Ornati A, Chiovato L, Polatti F; Hormonal management of migraine at menopause. Menopause International, 2009; 15(2): 82-86.

12. Braunwald E, Fanci AS, Hauser SL, Kasper DL,Longo DL, Jameson JL editors; Harrison's Principles of Internal Medicines. 17th edition, Mc Graw-Hill - Medical Publishing Division, New York, 2008: 85.

13. Brahmanand Tripathi, Sharangadhara Samhita of Acharya Sharanadharacharya (Deepika Hindi commentary), 2006 edition, Varanasi, Chaukhambha Surbharati Prakashan, Madhyamkhanda, Dwitiyodhyaya 2/143-145, Page no. 154

14. Lakshmipathi shastri, Yogaratnakara with Vidyotini Hindi commentary, edited by Bhishagratna Brakma Shankara Shashtri, 5th edition, Varanasi 1993, Chowkambha Sanskrit Samsthan, Page no.337.

15. Kanakhara B, Chaudhari V. A pilot study on clinical efficacy of Agnikarma and Pathyadi decoction (an Ayurvedic formulation) in the management of Ardhavabhedaka (migraine). Ayu. 2018 JanMar;39(1):56-61. doi: 10.4103/ayu.AYU_84_17. PMID: 30595636; PMCID: PMC6287398.

16. Ganesh Krushna Garde, Astanga Hridayam of Acharya Vagbhata, 2019 edition; Varanasi, Chaukhambha Surabharati Prakashana, Sutrasthana 20/1, Page no.85

17. Indradeva Tripathi, Arkaprakash of Lankapatiravan, Third edition 2011, Varanasi, Chaukhambha Krishnadas Academy, Dwitiya shatakam 2/3-6, Page no.20

18. Headache Classification Committee of the International Headache Society (IHS) The International Classification of Headache Disorders, 3rd edition. Cephalalgia. 2018 Jan;38(1):1-211. doi: 10.1177/0333102417738202. PMID: 29368949.

19. https://d45jl3w9libvn.cloudfront.net/jaypee/static/ books/9789385891700/Chapters/images/155-1.jpg

20. h t p s : / / e n.wikipedia.org/w i k i / Wong\%E2\%80\%93Baker_Faces_Pain_Rating_Scal e

21. Priyavrat Sharma, Charaka Samhita of Acharya Charaka, Eighth edition 2007; Varanasi, Chaukambha Orientalia publishers, Sutrasthana 4/47, Page no. 29

22. Kaviraja Ambikadatta Shastri, Sushruta Samhita of Acharya sushruta, 2018 edition, Varanasi (with Ayurved Tattva Sandipika, hindi commentary) Chaukhamba Sanskrit sansthan, Shareera-sthana $6 / 28$, page no 75

23. Indradeva Tripathi, Arkaprakash of Lankapatiravan, Third edition 2011, Varanasi, Chaukhambha Krishnadas Academy, Saptamam shatakam 7/13, Page no.112. 